\title{
Microbial quality of culled chicken layers in Penang, Malaysia
}

\author{
Ong Pek Geck ${ }^{1}$, Frederick Adzitey ${ }^{1,2}$, Raja Arief Deli ${ }^{1}$, Nurul Huda ${ }^{1}$ and Gulam Rusul Rahmat Ali $^{1}$ \\ 1. Food Technology Programme, School of Industrial Technology, Universiti Sains Malaysia, \\ USM 11800, Penang, Malaysia; 2. Animal Science Department, Faculty of Agriculture, University for \\ Development Studies, Box TL 1882, Tamale, Ghana \\ Corresponding author: Gulam Rusul Rahmat Ali, email: gulam@usm.my, Tel: +60122103046 Fax: +6046573678. \\ OPG: peggygeck@hotmail.com, FA: adzitey@yahoo.co.uk,RAD: deckwan@gmail.com, \\ $\mathrm{NH}$ : nrlhd@usm.my, GRRA: gulam@usm.my \\ Received: 02-04-2014, Revised: 05-05-2014, Accepted: 05-06-2014, Published online: 11-07-2014
}

doi: $10.14202 /$ vetworld.2014.478-482

How to cite this article: Geck OP, Adzitey F, Deli RA, Huda N and Ali GRR (2014) Microbial quality of culled chicken layers in Penang, Malaysia, Veterinary World 7(7): 478-482.

\begin{abstract}
Aim: To determine the microbial quality of culled chicken layers in Penang, Malaysia.

Materials and Methods: Samples were obtained from three layer farms (designated as Farm A, Farm B and Farm C). A total of 67 culled chicken layer samples consisting of egg wash water, chicken carcass rinse, drinking water, cloaca swab, feed and faeces were examined for enterobacteriaceae, total and faecal coliforms, and Escherichia coli using the procedures in the bacteriological analytical manual.

Results: The total plate count for bacteria ranged from $2.7 \times 10^{3} \mathrm{cfuml}^{-1}$ to $1.8 \times 10^{7} \mathrm{cfug}^{-1}$ (Farm A), $<1.0 \times 10^{2} \mathrm{cfuml}^{-1}$ to $1.7 \mathrm{x}$ $10^{6} \mathrm{cfug}^{-1}$ (Farm B) and $<1.0 \times 10^{2} \mathrm{cfuml}^{-1}$ to $3.1 \times 10^{6} \mathrm{cfug}^{-1}$ (Farm C). Enterobacteriaceae count ranged from $<1.0 \times 10^{2} \mathrm{cfuml}^{-1}$ to $3.5 \times 10^{6} \mathrm{cfug}^{-1}$ (Farm A), $<1.0 \times 10^{2} \mathrm{cfuml}^{-1} / \mathrm{cfug}^{-1}$ to $1.2 \times 10^{6} \mathrm{cfug}^{-1}$ (Farm B) and $<1.0 \times 10^{2} \mathrm{cfuml}^{-1} / \mathrm{cfug}^{-1}$ to $2.8 \times 10^{6} \mathrm{cfug}^{-1}$ (Farm C). Total and faecal coliforms ranged from $<3.0$ to $>1100.0$ Most probable number (MPN) $\mathrm{ml}^{-1} / \mathrm{MPNg}^{-1}$ for Farm A, B and C. Similarly, E. coli count for all the three farms ranged from $<3.0$ to $>1100.0 \mathrm{MPNml}{ }^{-1} / \mathrm{MPNg}^{-1}$. E. coli counts were very low for most of the samples examined except chicken carcass and faeces.
\end{abstract}

Conclusion: In general, Farm A had higher bacterial count, followed by Farm C and Farm B. This work gives an indication that pathogenic foodborne pathogens such as E. coli, Salmonella, Citrobacter, Enterobacter, Klebsiella, Shigella and Yersinia spp. may be present in culled chicken layers and consequently pose the risk of causing food poisoning or outbreaks.

Keywords: coliforms, culled chicken layers, E. coli, enterobacteriaceae, total plate count.

\section{Introduction}

Culled chicken layers or spent hens can be defined as the identification and removal of non-laying, unproductive or low producing hens from a laying flock. Due to the little value of culled chicken layers, they are usually slaughtered at the end of their productive lives. Hens can supply eggs for two to three years before being regarded as spent hens, but a depression of egg prices can shorten this time [1]. Pullets produced more eggs and utilized their feed more efficiently than spent layers although eggs from spent layers were heavier than that of pullets [2]. For the egg industry, culled chicken layers are considered as one of the by-products and these birds have low price [3]. Owing to the formation of large amounts of heat stable collagen caused by aging, the muscles of culled chicken layers become tough and unfavourable. These muscles have low functional properties and reduce its usefulness in whole meat food as well as its market value [4]. The tough texture of culled chicken layer meat causes them to be less popular among consumers.

However, the demand for spent hens can increase during festive occasions among culled chicken layer

Copyright: The authors. This article is an open access article licensed under the terms of the Creative Commons Attribution License (http://creativecommons.org/licenses/by/2.0) which permits unrestricted use, distribution and reproduction in any medium, provided the work is properly cited. consumers. Ariff [5] reported that the lack of broiler chickens supply in the market to fulfill consumers demand as well the tremendous increase in the price of broiler chickens during festivals forced many people to opt for spent hens instead of broilers. Furthermore, if meats from culled chicken layers are processed properly they can be good source of nutrients especially protein and amino acids $[4,6]$. Culled chicken layers are highly enriched with omega-3 fatty acid and high in myofibrillar protein, making them suitable raw materials for surimi-based products [7]. Spent hens have been reported to be good alternative for surimi-based product because their price is considerably cheap and their use ensures the improvement and utilization of waste/ underutilized resources [4]. Culled chicken layers have been used largely in the preparation of chicken soups and emulsified chicken products such as frankfurter and bologna. They have also been used in canned products including soups, sauces, stews, and gravies [8].

Microorganisms including Escherichia coli, Salmonella spp., Campylobacter spp., Shigella spp., Yersinia spp. and many more may be haboured in the intestines of animals, and can cross contaminate carcasses and meat products [9-18]. They are usually excreted into the environment via faeces, and can contaminate eggs, water, feed, soil, foods etc. As a 
Table-1: Total plate count of bacteria observed in culled chicken layers

\begin{tabular}{llll}
\hline Sample & Farm A & Farm B & Farm C \\
\hline Egg wash water & $2.7 \times 10^{3}-2.6 \times 10^{5} \mathrm{cfuml}^{-1}$ & $<2.5 \times 10^{3}-1.9 \times 10^{5} \mathrm{cfuml}^{-1}$ & $9.2 \times 10^{4}-2.0 \times 10^{5} \mathrm{cfuml}^{-1}$ \\
Chicken carcass rinse & $2.6 \times 10^{5}-2.9 \times 10^{5} \mathrm{cfuml}^{-1}$ & $2.0 \times 10^{5}-2.5 \times 10^{5} \mathrm{cfuml}^{-1}$ & $2.1 \times 10^{5}-2.3 \times 10^{5} \mathrm{cfuml}^{-1}$ \\
Drinking water & $1.4 \times 10^{4}-1.5 \times 10^{4} \mathrm{cfuml}^{-1}$ & $<2.5 \times 10^{3} \mathrm{cfuml}^{-1}$ & $<2.5 \times 10^{3} \mathrm{cfuml}^{-1}$ \\
Cloacal swab & $2.0 \times 10^{5} \mathrm{cfuml}^{-1}$ & $<1.0 \times 10^{2} \mathrm{cfuml}^{-1}$ & $<1.0 \times 10^{2} \mathrm{cfuml}^{-1}$ \\
Feed & $2.6 \times 10^{4}-2.9 \times 10^{4} \mathrm{cfug}^{-1}$ & $<2.5 \times 10^{3} \mathrm{cfug}^{-1}$ & $2.9 \times 10^{3}-3.1 \times 10^{4} \mathrm{cfug}^{-1}$ \\
Faeces & $1.8 \times 10^{7} \mathrm{cfug}^{-1}$ & $1.4 \times 10^{6}-1.7 \times 10^{6} \mathrm{cfug}^{-1}$ & $2.9 \times 10^{6}-3.1 \times 10^{6} \mathrm{cfug}^{-1}$ \\
\hline
\end{tabular}

consequence, humans can contract them from the consumption of contaminated food or contact with contaminated sources. In Malaysia, culled chicken layers are consumed especially among individuals that prefer tough chicken meat. Determining the microbiological status of culled chicken layers is essential because it will give an indication of the risk involved in contracting foodborne pathogens from the consumption of their meats and eggs.

Therefore, this study was carried out to determine the microbial load of culled chicken layers in three farms in Penang, Malaysia.

\section{Materials and Methods}

Location, duration and data collection: This study examined culled chicken layers and their environmental samples obtained from three different layer farms in Penang, Malaysia between November 2011 and April 2012 for their microbial quality. Samples from culled chicken layers were egg wash water, chicken carcass rinse, faeces and cloaca swab, while environmental samples were litter, feed and drinking water. These samples were stored under $4{ }^{\circ} \mathrm{C}$ during transportation and analyzed immediately upon arrival at the Food Microbiology Laboratory of the School of Industrial Technology, Universiti Sains Malaysia, Penang. Samples collected were analyzed for total aerobic bacteria, enterobacteriaceae, coliforms, faecal coliforms and $E$. coli.

Enumeration and confirmation of bacteria groups: Enumeration and confirmation of microbes was done using slightly modified method in the Bacteriological Analytical Manual of the Food and Drug Administration (BAM-FDA) [19, 20]. Egg wash water (10 ml), chicken carcass rinse $(10 \mathrm{ml})$, drinking water $(10 \mathrm{ml})$, feed $(10 \mathrm{~g})$, faeces (10 g) and cloaca swab (1 swab) were transferred into $90 \mathrm{ml}, 90 \mathrm{ml}, 90 \mathrm{ml}, 90 \mathrm{ml}, 90$ $\mathrm{ml}$, and $10 \mathrm{ml}$ of $0.1 \%$ saline bacteriological peptone water (SBPW), respectively and homogenized to serve as the $10^{-1}$ dilution factor. Subsequently, serial dilutions were made from the $10^{-1}$ to $10^{-6} \mathrm{in} 9 \mathrm{ml} \mathrm{SBPW}$.

Total aerobic plate count: Serial dilutions $\left(10^{-1}\right.$ to $\left.10^{-6}\right)$ were spread plated on plate count agar (PCA). Plates were incubated at $37{ }^{\circ} \mathrm{C}$ for $48 \pm 2 \mathrm{~h}$ under aerobic condition. After 48 hours of incubation, the number of colonies (25-250) formed on the plates were counted and the $\mathrm{cfug}^{-1}$ or $\mathrm{cfuml}^{-1}$ was calculated based on the guidelines given in the BAM-FDA.
Enterobacteriaceae: Similarly, serial dilutions $\left(10^{-1}\right.$ to $10^{-6}$ ) were spread plated on violet red bile agar (VRBG) plates. Plates were incubated at $37^{\circ} \mathrm{C}$ for $18 \mathrm{~h}$ to $24 \mathrm{~h}$ under aerobic condition. Counting and calculation of cfug $^{-1}$ or cfuml $^{-1}$ was done as in total aerobic plate count.

Total coliform, faecal coliforms and E. coli: The 3 tube most probable number (MPN) method of BAM-FDA was used. One $\mathrm{ml}$ of aliquot from dilution factors $10^{-1}$, $10^{-2}$ and $10^{-3}$ for each sample was transferred into 3 lauryl sulphate tryptose (LST) containing Durham tube. Inoculated LST tubes were incubated at $37{ }^{\circ} \mathrm{C}$ for $24 \mathrm{~h}$ to $48 \mathrm{~h}$. Positive LST tubes were indicated by gas production in the Durham tubes and turbidity of broths. Positive LST tubes were further transferred into brilliant green lactose bile (BGLB) and EC broths containing Durham tubes. Inoculated BGLB broths were incubated at $37{ }^{\circ} \mathrm{C}$ for $48 \mathrm{~h} \pm 2 \mathrm{~h}$ for the confirmation of coliforms. Inoculated EC broths were incubated at $45{ }^{\circ} \mathrm{C}$ for $24 \mathrm{~h}$ to $48 \mathrm{~h}$ for the enumeration of total faecal coliforms. A loopful of cultures from positive EC tubes were streaked onto Levine-EMB agar (L-EMB) plates and incubated at $37^{\circ} \mathrm{C}$ for $18 \mathrm{~h}$ to $24 \mathrm{~h}$ for the enumeration of $E$. coli. Presumptive $E$. coli colonies which appeared as dark centred and flat, with or without metallic sheen were purified on PCA. Purified E. coli isolates were subjected to recommended biochemical test (IMViC test) according to BAMFDA [20].

\section{Results and Discussion}

The results obtained for total aerobic bacteria, enterobacteriaceae, total coliform, faecal coliforms and $E$. coli counts are presented in Tables 1, 2, 3, 4, and 5 , respectively. From Table-1, samples collected from Farm B namely egg wash water, chicken carcass rinse, feed and faeces had lower total aerobic plate count as compared to the same samples collected from Farm A and $\mathrm{C}$ except drinking water and cloacal swab. Drinking water and cloacal swab from Farm B exhibited the same total aerobic plate counts with that of drinking water and cloacal swab from Farm C. Their total plate counts were $<2.5 \times 10^{3}$ cfuml $^{-1}$ (drinking water) and $<1.0 \times 10^{2} \mathrm{cfuml}^{-1}$ (cloacal swab). On the other hand, samples collected from Farm A notably, chicken carcass rinse, drinking water, cloacal swab, feed and faeces generally showed higher total aerobic plate counts. Drinking water from Farm B and C, faeces from Farm A and B, and cloacal swab from Farm $\mathrm{A}, \mathrm{B}$ and $\mathrm{C}$ showed no range for their total aerobic plate 
Table-2: Enterobacteriaceae count observed in culled chicken layers and their environmental samples

\begin{tabular}{llll}
\hline Sample & Farm A & Farm B & Farm C \\
\hline Egg wash water & $<1.0 \times 10^{2}-2.4 \times 10^{4} \mathrm{cfuml}^{-1}$ & $<1.0 \times 10^{2}-2.9 \times 10^{3} \mathrm{cfuml}^{-1}$ & $<2.5 \times 10^{3} \mathrm{cfuml}^{-1}$ \\
Chicken carcass rinse & $2.3 \times 10^{5}-2.6 \times 10^{5} \mathrm{cfuml}^{-1}$ & $1.7 \times 10^{5}-2.2 \times 10^{5} \mathrm{cfuml}^{-1}$ & $1.7 \times 10^{5}-2.0 \times 10^{5} \mathrm{cfuml}^{-1}$ \\
Drinking water & $<2.5 \times 10^{3} \mathrm{cfuml}^{-1}$ & $<1.0 \times 10^{2} \mathrm{cfuml}^{-1}$ & $<1.0 \times 10^{2} \mathrm{cfuml}^{-1}$ \\
Cloacal swab & $<1.0 \times 10^{2} \mathrm{cfuml}^{-1}$ & $<1.0 \times 10^{2} \mathrm{cfuml}^{-1}$ & $<1.0 \times 10^{2} \mathrm{cfuml}^{-1}$ \\
Feed & $<2.5 \times 10^{3} \mathrm{cfug}^{-1}$ & $<1.0 \times 10^{2} \mathrm{cfug}^{-1}$ & $<1.0 \times 10^{2} \mathrm{cfug}^{-1}$ \\
Faeces & $3.4 \times 10^{6}-3.5 \times 10^{6} \mathrm{cfug}^{-1}$ & $1.1 \times 10^{6}-1.2 \times 10^{6} \mathrm{cfug}^{-1}$ & $2.3 \times 10^{6}-2.8 \times 10^{6} \mathrm{cfug}^{-1}$ \\
\hline
\end{tabular}

Table-3: MPN for coliform observed in culled chicken layers

\begin{tabular}{|c|c|c|c|}
\hline Sample & Farm A & Farm B & Farm C \\
\hline Egg wash water & $<3.0->1100.0 \mathrm{MPNml}^{-1}$ & $<3.0-120.0 \mathrm{MPNml}^{-1}$ & $38.0->1100.0 \mathrm{MPNml}^{-1}$ \\
\hline Chicken carcass rinse & $210.0->1100.0 \mathrm{MPNml}^{-1}$ & $150.0->1100.0 \mathrm{MPNml}^{-1}$ & $160.0->1100.0 \mathrm{MPNml}^{-1}$ \\
\hline Drinking water & $240.0 \mathrm{MPNml}^{-1}$ & $<3.0 \mathrm{MPNml}^{-1}$ & $<3.0-3.6 \mathrm{MPNml}^{-1}$ \\
\hline Cloacal swab & $<3.0-23.0 \mathrm{MPNml}^{-1}$ & $<3.0 \mathrm{MPNml}^{-1}$ & $<3.0-11.0 \mathrm{MPNml}^{-1}$ \\
\hline Feed & $>1100.0 \mathrm{MPN} \mathrm{g}^{-1}$ & $>1100.0 \mathrm{MPN} \mathrm{g}^{-1}$ & $<3.0-43.0 \mathrm{MPN} \mathrm{g}^{-1}$ \\
\hline Faeces & $>1100.0 \mathrm{MPN} \mathrm{g}^{-1}$ & $>1100.0 \mathrm{MPN} \mathrm{g}^{-1}$ & $>1100.0 \mathrm{MPN} \mathrm{g}^{-1}$ \\
\hline
\end{tabular}

Table-4: MPN for faecal coliform observed in culled chicken layers

\begin{tabular}{|c|c|c|c|}
\hline Sample & Farm A & Farm B & Farm C \\
\hline Egg wash water & $<3.0->1100.0 \mathrm{MPNml}^{-1}$ & $<3.0-120.0 \mathrm{MPNml}^{-1}$ & 3.0- > $1100.0 \mathrm{MPNml}^{-1}$ \\
\hline Chicken carcass rinse & $120.0->1100.0 \mathrm{MPNml}^{-1}$ & $120.0->1100.0 \mathrm{MPNml}^{-1}$ & $160.0->1100.0 \mathrm{MPNml}^{-1}$ \\
\hline Drinking water & $14.0-23.0 \mathrm{MPNml}^{-1}$ & $<3.0 \mathrm{MPNml}^{-1}$ & $<3.0-3.6 \mathrm{MPNml}^{-1}$ \\
\hline Cloacal swab & $<3.0-15.0 \mathrm{MPNml}^{-1}$ & $<3.0 \mathrm{MPNml}^{-1}$ & $<3.0-11.0 \mathrm{MPNml}^{-1}$ \\
\hline Feed & $7.4-11.0 \mathrm{MPNg}^{-1}$ & $<3.0-9.2 \mathrm{MPN} \mathrm{g}^{-1}$ & $<3.0-3.6 \mathrm{MPN} \mathrm{g}^{-1}$ \\
\hline Faeces & $>1100.0 \mathrm{MPN} \mathrm{g}^{-1}$ & $210.0->1100.0 \mathrm{MPN} \mathrm{g}^{-1}$ & $>1100.0 \mathrm{MPN} \mathrm{g}^{-1}$ \\
\hline
\end{tabular}

Table-5: MPN for Escherichia coli observed in culled chicken layers

\begin{tabular}{llll}
\hline Sample & Farm A & Farm B & \multicolumn{1}{c}{ Farm C } \\
\hline Egg wash water & $9.2-21.0 \mathrm{MPNml}^{-1}$ & $<3.0-7.4 \mathrm{MPNml}^{-1}$ & $<3.0-9.2 \mathrm{MPNml}^{-1}$ \\
Chicken carcass rinse & $43.0->1100.0 \mathrm{MPNml}^{-1}$ & $20.0-460.0 \mathrm{MPNml}^{-1}$ & $27.0->1100.0 \mathrm{MPNml}^{-1}$ \\
Drinking water & $3.0-3.6 \mathrm{MPNml}^{-1}$ & $<3.0 \mathrm{MPNml}^{-1}$ & $<3.0 \mathrm{MPNml}^{-1}$ \\
Cloacal swab & $<3.0-7.2 \mathrm{MPNml}^{-1}$ & $<3.0 \mathrm{MPNml}^{-1}$ & $<3.0-3.6 \mathrm{MPNml}^{-1}$ \\
Feed & $3.0-3.6 \mathrm{MPN} \mathrm{g}^{-1}$ & $<3.0 \mathrm{MPN}^{-1}$ & $<3.0 \mathrm{MPN} \mathrm{g}^{-1}$ \\
Faeces & $210.0->1100.0 \mathrm{MPN} \mathrm{g}^{-1}$ & $64.0->1100.0 \mathrm{MPN} \mathrm{g}^{-1}$ & $150.0->1100.0 \mathrm{MPN} \mathrm{g}^{-1}$ \\
\hline
\end{tabular}

count. This is because all triplicate tests for these samples gave the same result.

From Table-2, drinking water, cloacal swab and feed from Farm B and Farm C exhibited the same enterobacteriaceae count of $<1.0 \times 10^{2} \mathrm{cfuml}^{-1}$ for drinking water and cloacal swabs, and $<1.0 \times 10^{2} \mathrm{cfug}^{-1}$ for feed. The enterobacteriaceae counts for drinking water $\left(<2.5 \times 10^{3} \mathrm{cfuml}^{-1}\right)$ and feed $\left(<2.5 \times 10^{3} \mathrm{cfug}^{-1}\right)$ from Farm A were found to be the same. On the other hand, egg wash water, chicken carcass rinse, drinking water, feed and faeces from Farm A were observed to have higher level of enterobacteriaceae as compared to the same samples collected from Farm B and C. It was also observed that feed from Farm A, Farm B and Farm C, cloacal swab and drinking water from Farm A, Farm $\mathrm{B}$ and Farm C, and egg wash water from Farm C showed no range for enterobacteriaceae count as all counts for these samples gave the same results. Besides that, chicken carcass rinses were found to have higher enterobacteriaceae counts than egg wash water samples. In general, faeces from Farm A, Farm B and Farm $\mathrm{C}$ have the highest enterobacteriaceae count as compared to other samples (egg wash water, chicken carcass rinse, drinking water, cloacal swab and feed). Faeces from Farm A had the highest level of enterobacteriaceae. Members of the enterobacteriaceae such as E. coli, Salmonella spp., Enterobacteria spp., Klebsiella spp. and Yersinia spp. are commonly found in the intestinal tract of animals, which are widely shed in faeces during defaecation [21].

The result obtained for the most probable number (MPN) of total coliform, faecal coliforms and E. coli is showed in Table-3, 4 and 5 respectively. Samples collected from Farm B which include egg wash water, chicken carcass rinse, drinking water, and cloacal swab generally had the lowest level of coliforms as compared to the same samples collected from Farm A and C. Farm A, however, was observed to have the highest level of coliform for samples such as chicken carcass rinse, drinking water and cloacal swab as compared to the same samples collected from Farm B and C. It was observed that feed from Farm A and B, and faeces from Farm A, B and C have the same level of coliform which was $>1100 \mathrm{MPNg}^{-1}$. Drinking water as 
well as the cloacal swab collected from Farm B was found to be least contaminated with coliforms.

Environmental and culled chicken layer samples thus drinking water, cloacal swab and feed from Farm A had higher level of faecal coliforms as compared to the same samples collected from Farm B and C. It was found that the level of faecal coliforms in chicken carcass in Farm A was the same as in Farm B with their MPN ranging from 120.0 to $>1100 \mathrm{MPNml}^{-1}$. Chicken carcass rinse from Farm $C$ was most contaminated with faecal coliforms with MPN number ranging from 160.0 to $>1100.0 \mathrm{MPNml}^{-1}$. On the other hand, egg wash water and some of the environmental and culled chicken layer samples which include drinking water, cloacal swab and feaces from Farm B had the lowest level of faecal coliforms as compared to the same samples collected from Farm A and C.

Egg wash water, chicken carcass rinse, drinking water, cloacal swab, feed and faeces from Farm A had the highest level of E. coli as compared to the same samples collected from Farm B and Farm C. Farm B was observed to have the lowest level of $E$. coli for egg wash water, chicken carcass rinse, cloacal swab and faeces. The level of E. coli in drinking water and feed from Farm B was found to be the same as the drinking water and feed collected from Farm $\mathrm{C}$ which was $<3$ $\mathrm{MPNml}^{-1}$. The MPN for $E$. coli in drinking water and feed from Farm A was found to be the same which was 3.0 to $3.6 \mathrm{MPNml}^{-1}$ for drinking water and 3.0 to 3.6 $\mathrm{MPNg}^{-1}$ for feed.

Overall, faeces from all the three farms were found to have the highest level of $E$. coli and the other bacteria compared to egg wash water, chicken carcass rinse, drinking water, and cloacal swab and feed samples. This is because E. coli and other bacteria are usually found in the intestines of humans and warmblooded animals [22] and it is usually shed into the environment via faeces [9]. Chicken carcasses are also mostly contaminated by bacteria during the removal of gastrointestinal tract [23]. Eggs in all the three farms were rolled onto a conveyor after laying. This practice kept the eggs off the floor all the time and thus reduces contact with faeces and litter, which could probably reduce the chances of faecal contamination of egg shells and consequently egg wash water.

\section{Conclusion}

This work gives an overview of the microbiological quality (total plate count, enterobacteriaceae, total coliforms, faecal coliforms and E. coli) of culled chicken layers and their related samples collected from 3 farms in Penang, Malaysia. The microbiological counts vary according to the 3 farms namely Farm A, Farm B and Farm C. Total plate count for bacteria was highest in egg wash water (Farm C), chicken carcass rinse (Farm A), drinking water (Farm A), cloacal swab (Farm A), feed (Farm A) and faeces (Farm A). Enterobacteriaceae counts for drinking water, cloacal swab and feed samples collected from Farm A, Farm B and $\mathrm{C}$ were low, except for faecal samples. All samples collected from Farm A were higher in E. coli as compared to samples collected from Farm B and C. MPN for $E$. coli for all the samples from all the three farms were considerably low and in a satisfactory level except for faeces and chicken carcass rinse samples.

\section{Authors' contributions}

GRRA and NH supervised the overall research work. OPG and RAD went to the field to collect the data and carried out the research. FA assisted in the laboratory work and wrote the first draft before being revised by all the authors. All authors read and approved the final manuscript.

\section{Acknowledgments}

The authors are thankful to the School of Industry Technology for the facilities provided to run this research. This research was funded by Postgraduate Research Grant Scheme of the Universiti Sains Malaysia and Malaysian Agricultural Research and Development Institute (MARDI).

\section{Competing interests}

The authors declare that they have no competing interests.

\section{References}

1. Li, C.T. (2006) Myofibrillar protein extracts from spent hen meat to improve whole muscle processed meats. Meat Sci., 72:581-583.

2. Yasmeen, F., Mahmood, S., Hassan, M., Akhtar, N. and Yaseen, M. (2008) Comparative productive performance and egg characteristics of pullets and spent layers. Pak. Vet. J., 28(1): 5-8

3. Singh, R.R.B., Rao, K.H., Anjaneyulu, A.S.R. and Patil, G.R. (2001) Moisture sorption properties of smoked chicken sausages from spent hen meat. Food Res. Int., 34:143-148.

4. Nowsad, A.A.K.M., Kanoh, S. and Niwa, E. (2000) Thermal gelation characteristics of breast and thigh muscles of spent hen and broiler and their surimi. Meat Sci., 54:169-175.

5. Ariff, M.M. (2006) Consumers dilemma during festival celebration, in Ministry of Domestic Trade Co-operatives and Consumerism. Available at: http://kpdnkk.bernama. com/newsBm.php?id=222026\&, Accessed on 05-03-2013.

6. Fuller, M.F. (2004) The Encyclopedia of Farm Animal Nutrition. Oxon, Cabi Publishing, p444.

7. Hur, S.J., Choi, B.D., Choi, Y.J., Kim, B.G. and Jin, S.K. (2011) Quality characteristics of imitation crab sticks made from Alaska Pollack and spent laying hen meat. LWT Food Sci. Tech., 44:1482-1489.

8. Lee, S.O., Min, J.S., Kim, I.S. and Lee, M. (2003) Physical evaluation of popped cereal snacks with spent hen meat. Meat Sci., 64:383-390.

9. Bhunia, A.K. (2008) E. coli, in Foodborne Microbial Pathogens: Mechanism and Pathogenesis, New York, Springer, Chap 10, p183-200.

10. Adzitey, F., Rusul, G. and Huda, N. (2012a) Prevalence and antibiotic resistance of Salmonella serovars in ducks, duck rearing and processing environments in Penang, Malaysia. Food Res. Int., 45: 947-952.

11. Adzitey, F., Rusul, G., Huda, N., Cogan, T. and Corry, J. (2012b) Prevalence, antibiotic resistance and RAPD typing of Campylobacter species isolated from ducks, duck rearing and processing environments in Penang, Malaysia. Int. J. Food Microbiol., 154: 197-205.

12. Adzitey, F., Liew, C.Y., Aronal, A.P. and Huda, N. (2012c) Isolation of $E$. coli from ducks and duck related samples. 
Asian J. Anim. Vet. Adv., 7:351-355.

13. Adzitey, F., Huda, N. and Gulam, R. (2011) Isolation of Campylobacter species from the large intestines of domestic Pekin ducks obtained from a Wet Market in Penang, Malaysia. Internet J. Food Safety, 13:170-174.

14. Adzitey, F. (2011) E. coli, it prevalence and antibiotic resistant in Malaysia-A mini review. Microbiol. J., 1:47-53.

15. Frederick, A. and Huda, N. (2011) Salmonellas, poultry house environments and feeds: a review. J. Anim. Vet. Adv., 10: 679-685.

16. Thaker, H.C., Brahmbhatt, M.N. and Nayak, J.B. (2012) Study on occurrence and antibiogram pattern of Escherichia coli from raw milk samples in Anand, Gujarat, India. Vet. World, 5(9): 556-559.

17. Karmi, M. (2013) Prevalence of methicillin-resistant Staphylococcus aureus in poultry meat in Qena, Egypt. Vet. World, 6(10): 711-715.

18. Kaushik, P., Anjay, Kumari, S., Bharti, S.K. and Dayal, S. (2014) Isolation and prevalence of Salmonella from chicken meat and cattle milk collected from local markets of Patna, India. Vet. World, 7(2): 62-65.

19. Maturin, L.J. and Peeler, J.T. (2001) Aerobic plate count, in:
Bacteriological Analytical Manual Online, United States Food and Drug Administration (FDA), Chap. 3. Available at: http://www.cfsan.fda.gov/ ebam/bam-3.html, Accessed on 05-03-2013.

20. Feng, P., Weagant, S.D., Grant, M.A. and Burkhardt, W. (2002) Enumeration of E. coli and the coliform bacteria, in: Bacteriological Analytical Manual Online, United States Food and Drug Administration (FDA), Chap. 4. Available at: http://www.fda.gov/food/scienceresearch/laboratory methods/bacteriologicalanalyticalmanualbam/ucm064948. htm, Accessed on 05-03-2013.

21. Blood, R.M. and Curtis, G.D.W. (1995) Media for 'total' enterobacteriaceae, coliforms and E. coli. Int. J. Food Microbial., 26:93-115.

22. Carmila, C., Maretto, D.A., Poppi, R.J., Sato, M.I.Z. and Ottoboni, L.M.M. (2011) Fourier transform infrared microspectroscopy as a bacterial source tracking tool to discriminate faecal E. coli strains. Microchem. J., 99:15-19.

23. Beauchamp, C.S. and Sofos, J.N. (2010) Diarrheagenic E. coli, in pathogens and toxins in foods: challenges and interventions (Juneja VK, Sofos JN. edn), Washington, ASM Press, p71-94. 